Syntax Fusion : Jurnal Nasional Indonesia

p-ISSN: -

e-ISSN : 2775-4440

Vol. 1, No. 7, Juli 2021

\title{
CULTURAL APPROACH TO TEACH ENGLISH: MUSIC AS A TEACHING AND THERAPY IN LEARNING ENGLISH
}

\author{
Nurma Dianti Putri, Natashah Mohd Ridwan, Dinda Sri Lestari, Nabilatul \\ Husniah dan Muhammad Taufik Ihsan. \\ UIN Sultan Syarif Kasim, Riau, Indonesia. \\ Email: inundianti@gmail.com natashahmohdridwan@gmail.com \\ dindaslestari07@gmail.com nabilatulhusniah@gmail.com \\ muhammad.taufik.ihsan@uin-suska.ac.id
}

\begin{abstract}
This research aims about how effective music as a teaching and therapy in learning English. Music makes ELT class more enjoyable and powerful for students. The explanation in this research is about what is the factors affecting pronunciation, what is the advantages of using song in ELT class and how can English songs facilitate English language learning. This research is using qualitative data collection for 50 students in Senior High School of St. Mary, Surabaya. The observation were made from the questionnaire, interviews and participants observation. One possible academic application is to encourage the students to listen to English music and input it in ELT class. Music, a mix of melody and lyrics, has numerous characteristic benefits, like a kaleidoscope of culture, expressiveness, creditability and helpful capacities, which render it a priceless hotspot for language educating. Learning through music is one of the best and easier for students to understand English. The way that English music for the students are frequently simple and straightforward point that they like most to learn. This research gives effective factors, benefits and facilitate in inserting music as a teaching and learning during ELT class.
\end{abstract}

Keywords : Music, English learning

\section{Introduction}

As we are probably aware music enjoys numerous benefits in our day to day existence. Music likewise can make a fascinating and an agreeable situation in any place in the event that you need to utilize it in a decent way. Utilizing music in English teaching is an extraordinary method to show language for students who cannot see completely all the lyrics however they actually pay attention to music and sing follow their teacher or music since they are extremely fascinating. Music has always been an enormous part in people's lives: it's ubiquitous, it surrounds us 
everywhere, and it's broadly accepted all round the world. Irrespective of the extent to which the capacity and sensitivity to music are programmed within the human brain or are by-products of other authorities and tendencies within the culture of music, without a doubt it plays a completely central and fundamental role. It seems that the fervour for music is deeply rooted in attribute. It is regarded in this approach because, for the vast majority of people, listening to music is associated with leisure time rather than work or education said Anna (Anna Kuśnierek, 2016). Seeing school, it's said that using songs during classes isn't so popular. It is perceived in that way because for majority people listening to music is connected with spare time, not with working or learning.

Music is heard in various spots we go, we hear it while beginning at the television at home. We hear it while shopping riding lifts, sitting in sitting regions and in various spaces as we approach each day life. People will feel pleased if they listen to music, even if it is intended to compensate for boredom or tension. Music and song may also reveal a person's personality or conduct. Based on Nurvia, song may be used as a teaching medium in the process of teaching and learning English at school in order to improve students' enthusiasm in learning, particularly in learning a foreign language (Sri Nurvia, 2016). Other than music, another basic component of melodies is verses which fill in as a direct certifiable wellspring of showing materials in unfamiliar classes, there have been plentiful exploration abroad on tunes as a bona fide training asset in language teaching. Melodies or musics are incredible to youngsters as well as influence their sentiments and energy levels. Without pondering melodies, individuals use tune and other melodic sounds to make wanted states of mind to satisfy themselves. Melodies regularly alluded to music are something to appreciate in development and dance, to stimulate, to bring back amazing recollections, to assist individuals with unwinding and even to center. Students should sing or listen an English song to enhance their vocabulary and grammar in writing and talking. All things considered, everybody is consistently ready to learn music with no more serious issues and additionally we are generally ready to sing a song, which has not been sung for a very long time, also, and this is the point, we recall the lyrics. There are dynamic and comfortable air by certain exercises box tunes, the students step up additional. The educator can partition the class into some appropriate gatherings ang trade if important. Songs, on the other hand, can help young learners to rehearse new sounds without becoming weary. Neil said the music also has a natural rhythm with repetitive beats that are comparable to the stress pattern of spoken English. These patterns result in certain songs that may be used to practise rhythm and stress. The song and play Girls and Boys Come Out may be utilised effectively to teach English rhythm and stress. They can sing or hit the dance floor with various ways that help them discover new words and recall this new word effectively and utilize the straightforward motions or non-verbal communication which the understudies can comprehend to do promptly these exercises are fascinating. 


\section{Methodology}

This research was done by analysing 50 students from the Senior High School of St. Mary in Surabaya and these data were collected by using qualitative data collection. The purpose of this research is to include music into the teaching and therapy of English learning. Firstly, this study begins with an introduction to incorporating music in the English learning process by the use of internet references. Next, the discussion in this study is about teaching of pronunciation using song as media and factors affecting pronunciation. Additionally, the advantages and benefits of using song in English learning and how can English songs facilitate English language learning. All of the materials in this study were obtained from a combination of papers, books, and internet resources. This research would help students for using music as a learning source which will be both beneficial and entertaining during the learning process.

\section{Discussion}

Maess and Koelsch emphasized that neurologist have tracked down that music and language preparing happen in a similar space of the mind, and there seem, by all accounts, to be matches in how melodic and etymological linguistic structure are handled (Maess, B., \& Koelsch, S., 2001). Learning a second language primarily includes learning the sound framework, syntax or grammar and vocabulary. Vocabulary learning assumes an essential part in learning another language. Laufer states that vocabulary is at the core of language learning and language use (Laufer, B., 1997). Considering the significant job credited to vocabulary in second language learning, one can certainly comprehend the significance of vocabulary learning too. Richard and Renandya comprehended that before vocabulary teaching and learning were frequently given little need in second language programs, yet also there has been a reestablished revenue in the idea of vocabulary and its job in learning and educating (Richard, J. C. \& Renandya, W. A., 2002).

At the same time, Hunt and Beglar referred to Richard and Renandya comprehensively talking, there are three ways to deal with vocabulary educating and learning: incidental, or non-direct learning (i.e., learning vocabulary as a result of doing different things like reading or listening), explicit or direct guidance (i.e.,diagnosting the words students need to know, introducing such words to the students and expounding their own insight and free technique improvement (i.e., working on speculating the importance of the words from setting and preparing students to utilize dictionaries) (Richard, J. C. \& Renandya, W. A., (2002). According to Milek, there are some criteria for choosing songs in teaching English which are, the ideal song, the lyrics of song, clear pronunciation and being rich in vocabulary (Milek, K., 1993). He added that a good song for teaching is one that is written primarily for the lyrics to be heard clearly, rather than songs with a lot of drums and loud guitars that are intended to be danced to. The lyrics of the song should be plainly 
discernible. Students will be unable to grasp the idea if each word is not clearly articulated; alternatively, they will become tense while listening. Because single artists are usually simpler to understand than most bands, it is preferable to choose a song performed by soloists. A chorus is frequently used alongside the lead singer's voice in bands.

\section{Teaching of Pronunciation Using Song as Media}

Songs can provide valuable speaking, listening and language practice in and out of the classroom. According to Arsyad, songs are taught as a media to communicate educational messages (Arsyad, A., 2006). Another definition of teaching songs as media involves communicative performances, whether printed or audiovisual, as well as the tools. Pronunciation refers to how a word or language is often spoken, as well as how someone utters a word. Szyszka also mentioned pronunciation is crucial since it helps with clarity and fluidity in communicating (Szyszka, M., 2017). According to Hornby, pronunciation is the way a language is pronounced, the way a word is spoken, and the way an individual delivers the meaning of words (Hornby, A. S., 1995). The above definitions imply that an individual's pronunciation is indeed the how the individuals communicate.

\section{Factors Affecting Pronunciation}

Kenworthy proposes some factors that affect student's pronunciation, for example, hearing, native language, age of learners, and motivation and concern for good pronunciation (Kenworthy, J., 1987).

\section{Hearing}

Some students have a hard time hearing certain aspects of pronunciation. They can interpret and create sounds accurately when they can hear appropriately. As a result, the key to effective pronunciation instruction is for students to listen and note how English is pronounced rather than producing perfect sound or intonation tones. The greater their awareness, the better.

\section{Native Language}

The student's native language will have the most impact on their pronunciation. Students will be able to diagnose their own difficulties if they are familiar with the sound system of their original language.

\section{Advantages and Benefits Using Song}

Listening to and responding to lyrics, like poetry, can help you avoid small conversation. Songs are authentic and easily accessible. Students will enjoy activities that teach them vocabulary, grammar, and cultural aspects. They can give beneficial speaking, listening, and language practise both inside and outside of the classroom. Songs may perform extremely effectively in the foreign language class for a range of factors, including the following:

\section{Songs almost always contain authentic, natural language}


This often contrasts the contrived, stilted language found in many student texts. Of course songs can also go to the other extreme by using overly crude, foul or otherwise objectionable language. With careful screening, an extensive library of usable songs for language learning can be compiled. Students can be introduced to a range of new vocabulary through songs Songs are almost often created for native speakers, hence they frequently include current language, idioms, and expressions.

\section{Students will be exposed to a variety of accents}

The advantage of using songs is that you can expose the students to a wide range of English. Through songs, British English, American English, and Caribbean English are all widely available. Songs from many locations, as well as a range of styles and forms, are well-represented in terms of accents. Gospel, soul, R\&B, Pop, Rock, Reggae, Jazz and more genres are all represented.

\section{Songs to be natural and enjoyable}

In English, there are a lot of funny, even ridiculous songs. Some vocalists have built a living off of them. (Has anyone heard of Ray Stevens?) They provide a fun, offbeat change of pace in the classroom.

\section{As a motivation}

On a very basic level, famous songs contact the existences of students, and are associated with their different advantages and ordinary encounters. Practically all mainstream songs are identified with a similar subject of companionship, love, dream, distress, and the rest which are the normal sensations of individuals. Since most youngsters these days are keen on a wide scope of social structures outside classes, musics might be a truly inspiring and interesting educating instrument. Encountering with films, TV, PC games and famous music is by all accounts profoundly persuading. Baoan once said in like manner, additional time and fixation to famous music in English unknown language homeroom would without a doubt build students' inspiration as study hall errands would consider their insight, their music and the jargon they definitely know from the songs (Baoan, W., 2008).

\section{How can English songs facilitate English language learning?}

\section{Stimulation of affective learning by songs}

Using English songs in EFL classes can help students achieve affective learning by creating a peaceful environment, lowering fear, promoting interests, and pushing them to learn the target language. Students will view English songs as fun rather than labor, making learning English through music enjoyable and relaxing.

\section{Arousal of motivation by English songs}

In emotional learning, motivation is crucial. Motivation is defined by Williams and Burden as "a condition of cognitive and emotional arousal that leads to a conscious decision to act and a time of sustained intellectual and/or physical effort in order to achieve a previously chosen goal (or goals)" (Williams, M, \& Burden, R. L., 1997). Motivation can be caused by both internal and external factors. 
Nurma Dianti Putri, Natashah Mohd Ridwan, Dinda Sri Lestari, Nabilatul Husniah dan Muhammad Taufik Ihsan

\section{Psychological Implications}

Larsen and Long and Williams and Burden as psycholinguistic researchers emphasized songs can engage language acquisition and learning in both hemispheres of the human brain (Larsen-Freeman, D.\&Long, M.H., 2000). Ellis said songs enter the human brain in a different way than speech (right hemisphere is more sensitive to nonverbal sound such as melodies and emotional colours of the message), and thus can stimulate language learning in the right hemisphere, whose involvement in language processing becomes more active in eliciting the overall meaning and delivering speech (Ellis, R., 1985).

\section{Research Methods}

This study is using qualitative data collection like questionnaire, interviews and participants observation from the 50 students of Senior High School of St. Mary, Surabaya.

Table 1 : Factors Affecting Pronunciation

\begin{tabular}{|l|c|c|}
\hline & Boys & Girls \\
\hline Hearing & 14 & 19 \\
\hline $\begin{array}{l}\text { Native } \\
\text { Language }\end{array}$ & 6 & 11 \\
\hline
\end{tabular}

Table 2 : Advantages and Benefits Using Song

\begin{tabular}{|l|c|c|}
\hline & Boys & Girls \\
\hline $\begin{array}{l}\text { Songs contain authentic, } \\
\text { natural language }\end{array}$ & 6 & 8 \\
\hline $\begin{array}{l}\text { Introduced new } \\
\text { vocabulary through } \\
\text { songs }\end{array}$ & 5 & 4 \\
\hline
\end{tabular}


Cultural Approach To Teach English: Music As A Teaching And Therapy In Learning English

\begin{tabular}{|l|c|c|}
\hline $\begin{array}{l}\text { Exposed to a variety of } \\
\text { accents }\end{array}$ & 3 & 3 \\
\hline $\begin{array}{l}\text { Songs are natural and } \\
\text { enjoyable }\end{array}$ & 8 & 4 \\
\hline $\begin{array}{l}\text { As a motivation } \\
\text { niva }\end{array}$ & 6 & 3 \\
\hline
\end{tabular}

Table 3 : How can English songs facilitate English language learning

\begin{tabular}{|l|c|c|}
\hline & Boys & Girls \\
\hline $\begin{array}{l}\text { Stimulation of affective } \\
\text { learning by songs }\end{array}$ & 10 & 10 \\
\hline $\begin{array}{l}\text { Arousal of motivation by } \\
\text { English songs }\end{array}$ & 7 & 9 \\
\hline $\begin{array}{l}\text { Psychological } \\
\text { implications }\end{array}$ & 8 & \\
\hline
\end{tabular}


Nurma Dianti Putri, Natashah Mohd Ridwan, Dinda Sri Lestari, Nabilatul Husniah dan Muhammad Taufik Ihsan

\section{Conclusion}

Through this paper, I might want to offer a solid expression that English songs assume a mystical part in showing new vocabulary and they ought to be utilized as a kind of advantageous materials in education. Dynamic vocabulary learning is an action that is only here and there gave any consideration in most language classrooms. So, songs can be of incredible assistance. Numerous words that arrangement with a specific subject or feeling show up in a tune. In certain tunes specific linguistic highlights happen with incredible recurrence. Such musics, subsequently, can be utilized as a type of support for the specific primary item. Songs can give great talking, listening, and language practice inside and outside the gathering room. Songs are instructed as a medium to pass on instructive messages.

In conclusion, songs give an agreeable method to present or review vocabulary, teach a good pronunciation, deliver a great structures and sentence patterns in a novel manner, "it's an imaginative and effective technique to utilize English songs to improve students' listening and talking additionally" (Lynch, L., 1993). 
Cultural Approach To Teach English: Music As A Teaching And Therapy In Learning English

\section{Bibliografi}

Anna Kuśnierek,(2016). The role of music and songs in teaching English vocabulary to students. Word scientific new

Arsyad, A. (2006). Media pembelajaran. Jakarta: PT. Rajagrafindo Persada

Baoan, W. (2008). Application of popular English songs in EFL classroom teaching. Humanising Language Teaching 10,3

Ellis, R. (1985). Understanding second language acquisition. Shanghai : Shanghai Foreign Language Education Press

Hornby, A. S. (1995). Oxford advanced learners dictionary. Oxford: Oxford University Press

Kenworthy, J. (1987). Teaching English pronunciation. London: Longman

Larsen-Freeman, D. \& Long, M. H. (2000). An introduction to second language acquisition research. Shanghai: Shanghai Foreign Language Education Press Laufer, B. (1997). The lexical plight in second language teaching. Cambridge: Cambridge University Press

Lynch, L. (1993). Using popular songs to improve language listening comprehensive skills. Pg: 23

Maess, B., \& Koelsch, S. (2001). Musical syntax is processed in Broca's area: An MEG study. Nature Neuroscience 4, 540-545.

Milek, K. (1993). Using songs as a teaching aid in a grouproom setting. Oxford : Oxford University Press

Neil T. Millington,Using Songs Effectively to Teach English to Young

Learners:Ritsumeikan Asia Pacific University, Japan

Richard, J. C. \& Renandya, W. A. (2002). Methodology in language teaching : An anthology of current practice. Cambridge: Cambridge University Press

Sri Nurvia(2016).Using Song In Teaching English Speaking Skills

For Young Learners: English Language Teaching Department, Tarbiyah and Teacher Training Faculty, Syekh Nurjati State Islamic Institute Cirebon

Szyszka, M. (2017). Pronunciation learning strategies and language anxiety. Amsterdam: Springer

Williams, M, \& Burden, R. L. (1997). Psychology for Language Teaching. Cambridge: Cambridge University Press 